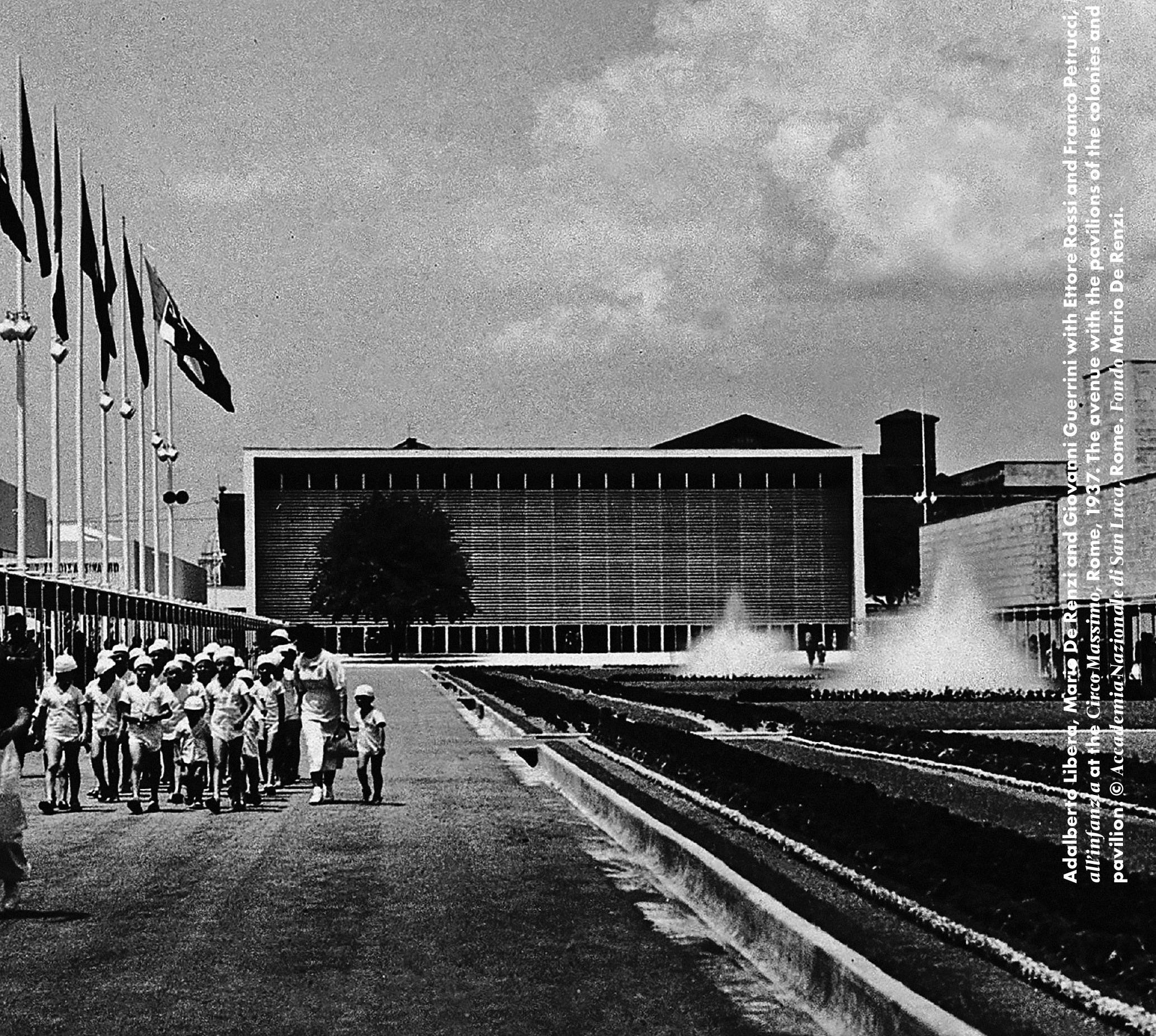




\title{
Holiday colonies for Italian youth during Fascism
}

\author{
BY MARCO MULAZZANI
}

\begin{abstract}
Thousands of summer colonies were created for youth in Fascist Italy 11922 - 1943). Most were temporary structures set up to assist children only during the daytime; dozens became the concrete symbol of the totalitarian project undertaken by Fascism to shape "new Italians" starting from childhood. Actually the colonies promoted by the organizations of the regime, state agencies and industrial companies, due to a lack of precise "models" of reference for the architects involved, present a highly varied expressive panorama, reflecting the complexity of the architectural debate in those years and the difficulties that faced any truly modern approach to architecture.
\end{abstract}

On 20 June 1937, in the enormous space of the Circo Massimo in Rome, Benito Mussolini (1883-1945) presented the Mostra Nazionale delle colonie estive e dell'assistenza all'infanzia (National exhibition of summer camps and assistance to children) - "an exhibition that is the only one of its kind," Giuseppe Pagano (1896-1945) would opine in the magazine Casabella, "which demonstrates the interest of the Fascist State in the health of children" and its commitment to "a complex, complete undertaking, namely that of the protection and propagation of our lineage" ${ }^{2}$. Spread across over 20,000 square meters, the exhibition was composed of pavilions in a linear sequence, with the entrance and the assembly hall at the two extremities. The sequence began with a space on tourism and on the "fanciullo nellarte" [boys in art], and continued with pavilions of the Opera Nazionale Maternità e Infanzia (ONMI), of assistance agencies (Ministry of the Interior, Red Cross, Social Welfare), education (National Education Ministry), rehabilitation of minors (Ministry of Justice), summer camps Partito Nazionale Fascista (PNF), semi-public and private operators, the Fasci Italiani all'Estero [Italian Fascists abroad], the Opera Nazionale Balilla (ONB), merchandise sectors, and the activities of Fascist youth organizations. This itinerary was paced by tableaux vivants in which dozens of toddlers, children and adolescents (male and female), observed but not disturbed, were subjected to medical examinations and heliotherapy treatments, played and learned in a kindergarten and a school, indulged in the vacation activities of a "model colony" created for the occasion, setting up campsites, doing calisthenics and taking turns at guard duty ${ }^{3}$.

At the same time, a few kilometers to the north, in the setting of the Foro Mussolini, another exhibition was being held, it too the only one of its kind: a "summary" of the construction activities of $\mathrm{ONB}^{4}$, the organization assigned the task of educating young people regarding a "Fascist lifestyle". Founded in 1926, the ONB developed its political-pedagogical project to the point of becoming a sort of parallel institution, in competition with public schooling. Its president Renato Ricci (1896-1956) had built one of the sacred sites of Fascism, Foro Mussolini, consecrated to the cult of the Duce and deployed for the training of educators of the younger generations. In the same spirit, Ricci planned the creation of hundreds of Case Balilla scattered across the nation: constructions conceived not as simple outposts for the offices of the organization, but as centers of physical, cultural and professional activity; works of architecture with a precise identity, specifically created and perfected to be clearly associated with ONB.

At the exhibition of summer camps the ONB took part with its own pavilion, presenting a partial representation of an activity that could then be grasped in its totalitarian political dimension in the show at Foro Mussolini ${ }^{5}$. So while the two events seemed to share in the icastic representation of the life of the new Italian - from the cradle to enrollment in the ranks of the PNF - and in the celebration of the advent repeatedly envisioned by Mussolini of the "fourth great historical epoch of the Italian people, (...) the epoch of the Black Shirts, in which there will be complete Fascists, namely those born, raised and living entirely in our climate" ${ }^{6}$, their intrinsic difference should not be overlooked. The exhibition at Foro Mussolini was the coherent expression of the "most Fascist of all Fascist organizations", bent on "the most gigantic experiment in education to the State in all of history"; the exhibition at Circo Massimo documented the wide-ranging and varied activities in the area of assistance for children and youth, carried out by PNF but also by other public and private players. This difference is reflected in the works of architecture made for Italian youth, especially in the history of the vacation colonies.

In Italy the creation of camps was a phenomenon that began prior to Fascism, dating back to the mid- $18^{\text {th }}$ century. In 1918 a ministerial survey counted about one hundred 


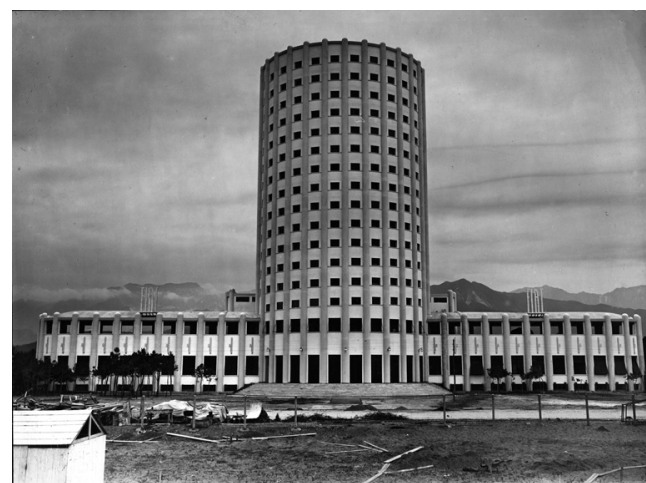

01

Vittorio Bonadè-Bottino, FIAT "torre balilla" colony, Marina di Massa, Massa-Carrara, 1933. @ Archivio storico FIAT, Turin.

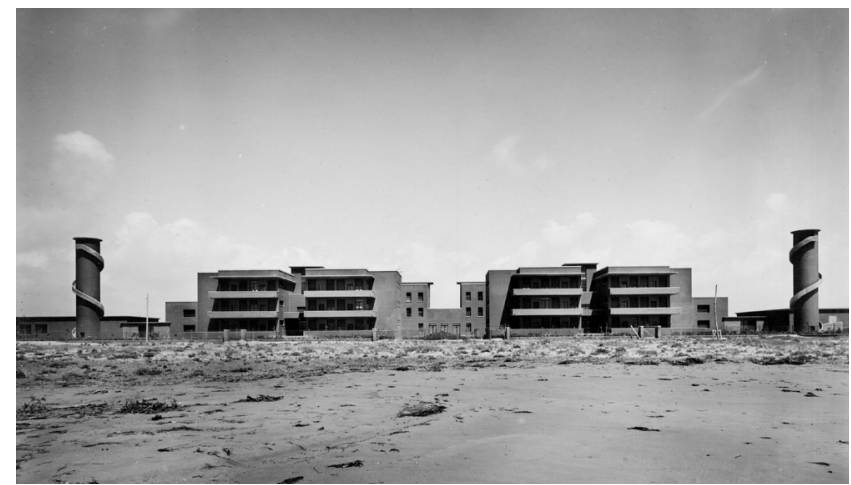

02 Angiolo Mazzoni, colony for Opere di previdenza dei ferrovierie dei postelegrafonici, Calambrone, Tirrenia di Pisa, 1931 - 1933. @ MART-Museo di arte moderna e contemporanea di Trento e Rovereto. Fondo Angiolo Mazzoni. such facilities ${ }^{8}$, including therapeutic centers like the "seaside hospices" created to cure childhood diseases like tuberculosis and scrofula, and others more specifically for "vacations", often based on private and philanthropic initiatives, with educational and social missions, aimed at the offspring of the poorer classes or precise categories of workers. The need for therapeutic specialization of permanent clinics and for the creation of more temporary camps for social and preventive initiatives was already clear at the first Italian conference of local agencies, organized in Milan in October 1920 on the theme of colonies in healthy climes. The insertion of initiatives for the assistance of children in the overall context of State policies aimed at the "physical and moral reconstruction of the race" became one of the strong priorities of Fascism. To this end, in 1925 the ONMI ${ }^{9}$ was created, an agency whose main goals included the protection and assistance of needy or abandoned mothers, children up to five years of age, abandoned or abused children under 18, also through the creation of counseling centers, kindergartens, vocational schools and - of course - colonies. In this sector the task of the ONMI was to control the activities of the existing facilities and to found new ones, operating in collaboration with the Fascifemminili (the women's section of the Fascist party, an organization created in 1925) for the management of the vacation camps ${ }^{10}$. The number of new colonies created in the second half of the 1920 s reflects the importance assigned to this area by the party: in 1926 the temporary seaside and mountain camps organized by ONMI and Fasci femminili were slightly more than 100 in number, serving about 60,000 children; in 1930 , thanks to the spread of heliotherapy day camps, the temporary facilities run by PNF reached a level of 700 , and the children assisted reached $150,000^{11}$. Important questions remained to be resolved, however, such as the lack of control of assistance initiatives organized outside the Fascist party - particularly, though not exclusively, the many company camps - and the lack of coordination of the activities of the individual federations, with their tendency for economic reasons to promote the creation of day camps made with tents and temporary structures. There was also the tendency to reutilize existing buildings for the (still not very numerous) sleepover camps, implying the absence of design considerations for this type of construction. The crucial theme of the definition of the characteristics of architecture specifically made for "little Fascists" was not approached even after the creation in 1931 of the Ente Opere Assistenziali (EOA), charged by the PNF with an overall reorganization of the activities of assistance to the population.

In the sector of the colonies, the EOA operated with a certain efficacy to regulate assistance procedures and management of facilities (in exponential growth since 1931, in the wake of the day camps), but it lacked the administrative clout to have a real impact on the activities of other agencies operating in the same field (sectors of the State administration, industrial groups, associations, etc.). The hypothesis of collaboration with the ONB generally remained limited to the use of its educators and did not cover the definition of a program of construction of new colonies. In this sense, precisely the comparison with the "pupil of the regime", the ONB of Ricci, reveals the difference in reach of the two organizations. Starting in 1928, Ricci prepared a manual — written by Enrico del Debbio (1891-1973), architect of the Foro Mussolini — with a series of projects of Balilla centers of small, medium and large size,

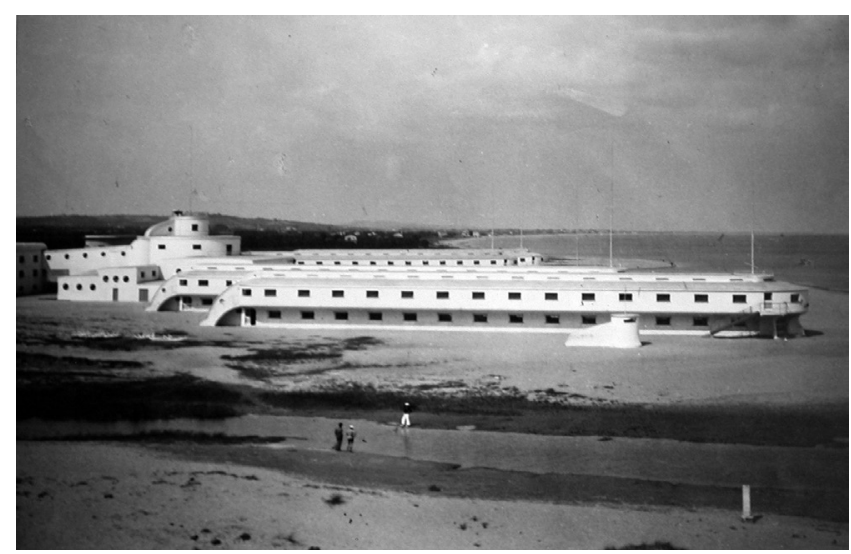

03 Clemente Busiri Vici, the "xxviII ottobre" colony ("le navi"), Cattolica, Rimini, 1932-1934. (C) Archivio Clemente Busiri Vici, Rome. 
as a reference guide for the creation of new constructions ${ }^{12}$. From 1932 on, Ricci selected a small group of absolutely trusted architects, personally commissioning them to design the Balilla centers and, in 1933, he appointed the young Luigi Moretti (1907-1973) as the director of the technical division of ONB. Luigi Moretti's contribution consisted of developing and perfecting a "new architectural type", which had "no precedents, in Italy or elsewhere" and could "only find certain affinities with the 'gymnasia' of the Greeks and Romans", constructions that "since then (...) have been considered the highest expression of political civilization"13. This objective was pursued through the construction of some “exemplary" works of architecture, but also by preparing procedural and technical standards that translated the principle of centralized decision making on an operative level ${ }^{14}$.

In the ambit of the camps, no comparable effort to define a "new architectural type" can be seen. Apart from the interesting project for a seaside colony for three hundred children at Castelfusano (Rome) developed by the young Mario Ridolfi (1904-1984) in 1929 in a degree thesis at the School of Architecture of Rome, in the few projects built towards the end of the 1920s we find substantial continuity with those of the previous decade - not by chance, no significant traces of this initial series of constructions have remained in the leading architecture magazines. The claim to a specificity of Italy where unlike what happens in other nations the Fascist regime is directly engaged in the action of promotion, coordination and management of camps, so that "the Italian child [is] cared for and made vigorous, with a unity of methods and orientations in all the regions"15, has not yet been transformed into clear awareness of the "educational" role that can be played by architecture.

The situation changed during the course of the 1930s. The gradual unfolding of the totalitarian program of the regime — of mass "conversion" to Fascism - was accompanied by intensification of the ideological-formative core of a model of assistance based primarily on processes of prevention and care. The sleepover camps, besides providing vacation facilities, offered an opportunity to initiate children from an early age into the experience of Fascist collective discipline ${ }^{16}$. Nevertheless, while the political context could provide programmatic indications to a generation of designers willing to demonstrate, in concrete projects, the full correspondence of modern architecture to the "new and more correct 'order of values" 17 of the Fascist era, typological considerations were still lagging behind. In fact, regarding the approach taken by architects to this design theme, it has even been observed that every one of them did as he saw fit ${ }^{18}$.

The hypothesis of substantial autonomy of architectural choices is confirmed by an overview of the slightly less than fifty colonies designed and built in the 1930s, also due to the fact that they were made for a variety of different clients: local federations of the PNF, Fasci Italiani all'Estero ${ }^{19}$, ONB, sectors of the national administration, industrial groups (FIAT, Piaggio, Montecatini, AGIP, Snia Viscosa, Dalmine, ILVA, Marzotto, Rossi), the national association of war veterans, the Italian Red Cross, healthcare consortia, the city government of Rome, and so on. Alongside works of modern architecture of great quality that were to become emblems, in Italy and abroad ${ }^{20}$, of the efforts of the regime to promote the "health of the race", there were still examples of a more dated design approach; others were marred by naive symbolism and an approach to the "modern" limited only to the language, often with banal results. These latter orientations are fully represented in the "linear city" for children built at Tirrenia di Pisa, in the municipality of Calambrone. From 1931 to 1939, along two kilometers of coast, seven colonies were built, designed by architects of varying levels of ability for a variety of clients: Ugo Giovannozzi (1876-1957) for the Federazione fascista of Florence (1931-1932), Angiolo Mazzoni (1894-1979) for Opere di previdenza dei dipendenti di poste e telegrafi e delle ferrovie (1931-1933), Ghino Venturi (1884-1970) for the Livorno Hospital (1932-1933), Paolo Baldi Papini for the Cassa di Risparmio di Pistoia e Pescia (1932-1933, for the children of airmen), Mario Paniconi (1904-1973) and Giulio Pediconi (1906-1999) for Fasci Italiani all'Estero (1933-1935), Gino Steffanon for the Consorzio antitubercolare provinciale of Pisa (1933-1938), Gregorio Birelli and Dagoberto Ortensi (1902-1975) for Opere di assistenza del personale antincendio (1939-40). The range of solutions is wide and imaginative, with layouts in the form of a fascis (Ghino Venturi), an airplane (Paolo Baldi Papini) or the figure of a child with raised arms (Gino Steffanon), while the elevations attempted troublesome mediations between "classic" and "modern". The colonies by Angiolo Mazzoni and Paniconi \& Pediconi (architectural firm, 1934-1984) were definitely of greater interest. The first, conceived perhaps as a "futurist" view from above (Tato, Volando sul Calambrone), has a symmetrical plan with "duplicated" volumes (reflecting the dual agencies of services for postal and railway workers). The architectural solutions, however, are those of Angiolo Mazzoni's repertoire, as seen in the many post offices and railway stations he designed - tall water towers with tanks wrapped in spiral staircases, glass cylinders featuring the rhythm on the outside of uprights in solid marble at the sides of the entrance, the red-orange colors of the stucco and the casements, used by the architect in constructions of various kinds. The girls' colony by Paniconi \& Pediconi stands out for its greater simplicity of forms - amidst exceptions: the curved profile of the roof of the outdoor chapel, the cylindrical tower for the administrative offices - and by a well-organized layout in separate volumes, connected by sheltered walkways.

Symbolism is the distinctive feature of three of the most famous colonies built in the 1930s: le navi, namely the XXVIII ottobre seaside camp designed by Clemente Busiri Vici (18871965) at Cattolica (Rimini) in 1932-1934 for Fasci Italiani all'Estero, and the two "Balilla towers" built by the engineer Vittorio Bonadè Bottino (1889-1979) for FIAT at Marina di Massa (Massa-Carrara) and Salice d'Ulzio (Turin), respectively in 1933 and 1937. With one important difference: while Clemente Busiri Vici only partially sacrifices the functional quality of the complex due to an architectural and layout solution that suggests a naval squadron (an image that was clearly appropriate for children returning to the homeland of their parents for summer vacations), 


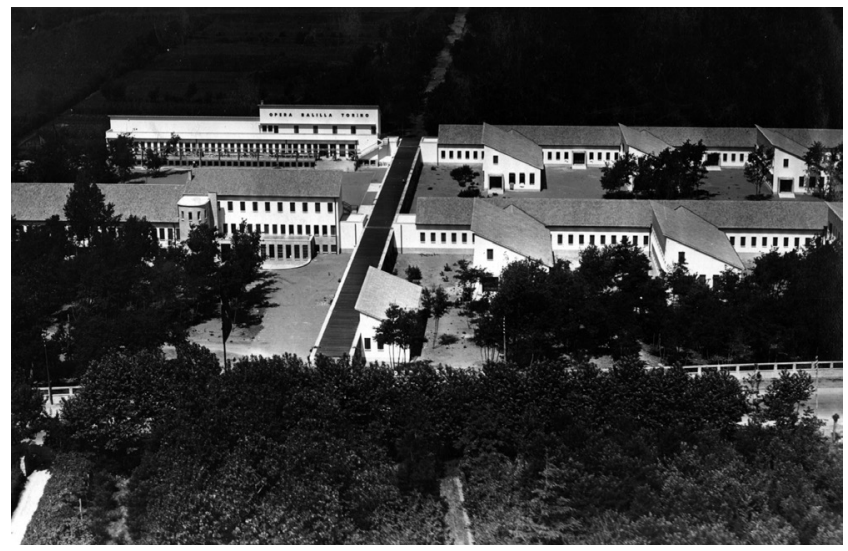

04 Francesco Mansutti and Gino Miozzo, colony for the onB federations of Milan and Turin, Marina di Massa, Massa-Carrara, 1936- 1937. (C) MART-Museo di arte moderna e contemporanea di Trento e Rovereto. Fondo Angiolo Mazzoni.

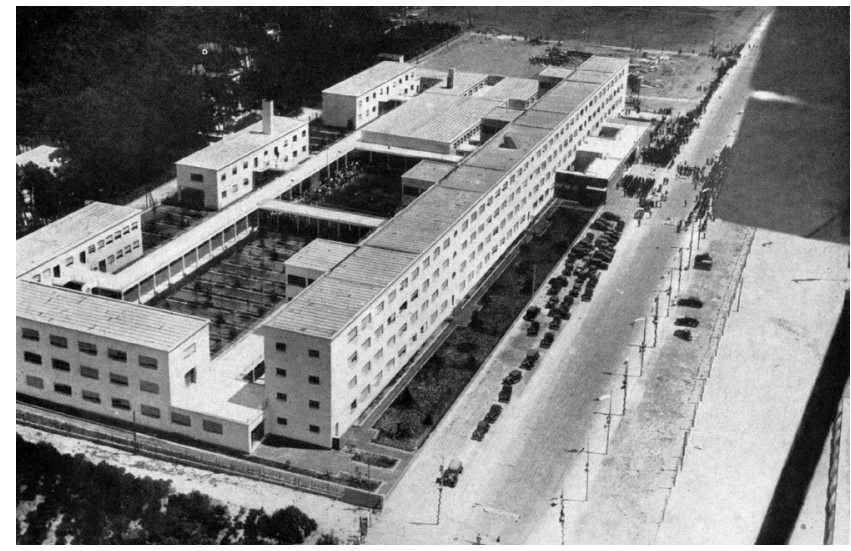

05 Ettore Sottsass and Alfio Guaitoli, colony for the Federazione torinese dei fasci di combattimento, Marina di Carrara, Massa-Carrara, 1937- 1938 C MART-Museo di arte moderna e contemporanea di Trento e Rovereto. Fondo Angiolo Mazzoni.
Vittorio Bonadè Bottino bends even good sense to the aims of a self-referential form (his hotel-tower at Sestriere, in fact, are dated 1932-1933). In both the seaside and the mountain colony, the dormitories are placed along a helical ramp (in a linear arrangement, they respectively measure 420 and 300 meters) and are open to a central full-height shaft: the inevitable slope of the floor in the dormitories meant that the feet of the beds had to have different lengths.

Examples of a superficial take on the modern language can be seen in the colony by the engineer Giuseppe Peverelli (1893-1969) for the Federazione fascista of Novara at Miramare di Rimini (1934), and the later "Costanzo Ciano" colony by Mario Loreti (1889-1968) for the Federazione dei fasci di combattimento of Varese at Milano Marittima, Ravenna (1937-1939), both marked by rigid symmetry of the plan and a theatrical, monumental interpretation of devices like staircases and ramps. The Montecatini colony at Cervia, Ravenna (1938-1939) by Eugenio Faludi (1899-1991) in collaboration with the technical division of the client company was more consistent with "functionalist" premises, with its free layout and the remarkable concrete skeleton of the tower-reservoir-observatory that reached "level 50 ". AGIP’s "Sandro Mussolini” colony at Cesenatico, ForlìCesena (1937-1939) by Giuseppe Vaccaro (1896-1970) - a parallelepiped raised on pillars to permit visual and spatial continuity from the countryside to the beach - is unanimously indicated as the most effective synthesis of functional, spatial and figurative values in a construction made for this purpose. It is a work of architecture of "direct beauty”, Gio Ponti (1891-1979) writes in 1943, achieved "without aesthetic delicacies or complications of a cerebral order" 21 ; an "absolute" form that nevertheless springs from the personal research of Vaccaro.

Similar considerations can be reached if we extend the analysis to other works built in the same decade: the "colony-hotel” by Gaspare and Luigi Lenzi (architectural firm) for the recreation center for healthcare workers in Rome at Santa Severa (1933-1934), and the "skyscraper" by Camillo
Nardi Greco (1887-1968) in Chiavari (1935); the almost rural "seaside village" by Francesco Mansutti (1899-1969) and Gino Miozzo (1898-1969) for the ONB federations of Milan and Turin at Marina di Carrara (1936-1937), and the "industrial organism" of Ettore Sottsass (1917-2007) and Alfio Guaitoli (1898-1939) for the Federazione torinese dei fasci di combattimento at Marina di Massa (1937-1938); the massive Dalmine colony of Giovanni Greppi (1894-1960) at Riccione (1933), the elegant and essential facilities by Cesare Fratino (1886-1969) and Enrico Griffini (1887-1952) for the Lino Redaelli company in Cesenatico (1937-1938) and by Giulio Minoletti (1910-1981) for the Ente nazionale fascista della mutualità scolastica at Formia (1938-1939); among the mountain colonies, above all those of Gino LèviMontalcini (1902-1974) for the above-cited Federazione torinese at Bardonecchia (1938) and by Luigi Daneri (1900-1972) for Piaggio at Santo Stefano d'Aveto, Genoa (1939); among the heliotherapy colonies, the function construction by Enrico Del Debbio (1891-1973) for ONB at Monte Mario, in the Foro Mussolini area (1933-1934), and the lucid architecture built by вв PR (architectural firm) at Legnano (1938).

Apart from the differences due to location, and the variation of area and volume based on the number of children to be hosted (from a minimum of 100 to 1500), the layout organization and the morphological and architectural characteristics of the above-mentioned colonies cannot plausibly be traced back to a single matrix. At the same time, if we examine the careers of the designers, we find that the commissions are nearly always the result of direct, private or institutional relationships between the clients and the architects ${ }^{22}$. Very few competitions were held for the design of colonies, and they rarely led to positive results, as demonstrated by the competition organized in 1934 by the Federazione torinese dei fasci di combattimento for a colony at Riccione, or by the episode of the Montecatini colony ${ }^{23}$. In any case, the competitions set specific parameters - in terms of functions and dimensions - but they did not set "norms". Confirmation of this fact also comes from the first 
(and only) national competition for standard colony models held in 1937, precisely at the time of the summer camps exhibition: the results - evidently of little interest - were announced only through the newsletter of the Union of Architects, printed as a supplement without illustrations of the magazine Architettura ${ }^{24}$.

The summer camps exhibition at the Circo Massimo and that of the ONB at Foro Mussolini coincided with a flex point in the progress of policies of assistance and education of the younger generations of Fascism. At the start of the month of June, shortly prior to the opening of the summer camps exhibition, the EOA chapters were dismantled, while their functions in the sector of climate facilities remained with the PNF; at the end of October, with the founding of the Gioventù Italiana del Littorio (GIL), the experience of the ONB came to an end, as it too was "absorbed" by the PNF, while a party directive assigned the GIL the task of "surveillance and control of all the climate camps or similar institutions founded and managed by any parties", and the commander-general of the organization (namely the secretary of the PNF Achille Starace [1889-1945]) was granted the power to authorize or deny approval for the creation of new structures ${ }^{25}$. The regrouping under the control of the PNF of all the activities of assistance to children and the political education of the new generations, however, did not have a significant impact on the architecture of the vacation colonies. Instead, the strategy of the party, confirmed by the congress organized in July 1937 during the exhibition, focused on limiting the number and encouraging a further increase of the day camps, in order to extend climate benefits to all school-age children ${ }^{26}$. So it should come as no surprise that the Regolamento delle colonie climatiche issued in 1939 by PNF-GIL was limited to providing indications of a general character on the organization of the spaces, without addressing the matter of architectural characteristics; instead, the regulations went into detail on certain aspects like medical visits, uniforms, nutrition and daily activities, from reveille (7.00 AM) to lights-out (9.00 PM), between two ritual moments, at sunrise and sunset, for saluting the flag. In 1939 Armando Melis (1889-1961) published a functional scheme for a seaside camp that seems to translate the indications of the Regolamento delle colonie climatiche of the PNF, and is in fact just a diagram of functions and flows. In 1940, speaking of the seaside colonies, Gio Ponti still complained of the lack of "official texts on this subject", and suggested taking "the technically finest examples (...) as a model to further perfect in the future" 27 .

This is perhaps the meaning that can be attributed to the two special issues devoted in 1941 by Costruzioni Casabella to the seaside, mountain and heliotherapy colonies ${ }^{28}$. The first true assessment of ten years of projects and constructions in this sector, the "repertoires" were introduced in critical essays by Mario Labò (1884-1961) that took their cue from the attempt to define - beyond the functional requirements, seen as an "implicit preliminary" — the specific characteristics of the colony typology. These buildings, Labò writes, replicate "somehow the tradition of the Hellenic 'gymnasia', which as we know were not just places for gymnastics"; their arrangement "at once contains the hotel, the school, and also the clinic. But the loftier moral requirements lie outside the practical field". It is significant, however, that these "moral requirements" are not sought in the compliance with an ideology inculcated in the younger generations, but in the work of architects and their creations. In fact, according to Mario Labò, a grave responsibility lies with those who have to create the facilities of these youthful gatherings:

\section{Everything in them, from the abstract lines and volumes to} the organization of the plans, which trace the itineraries of

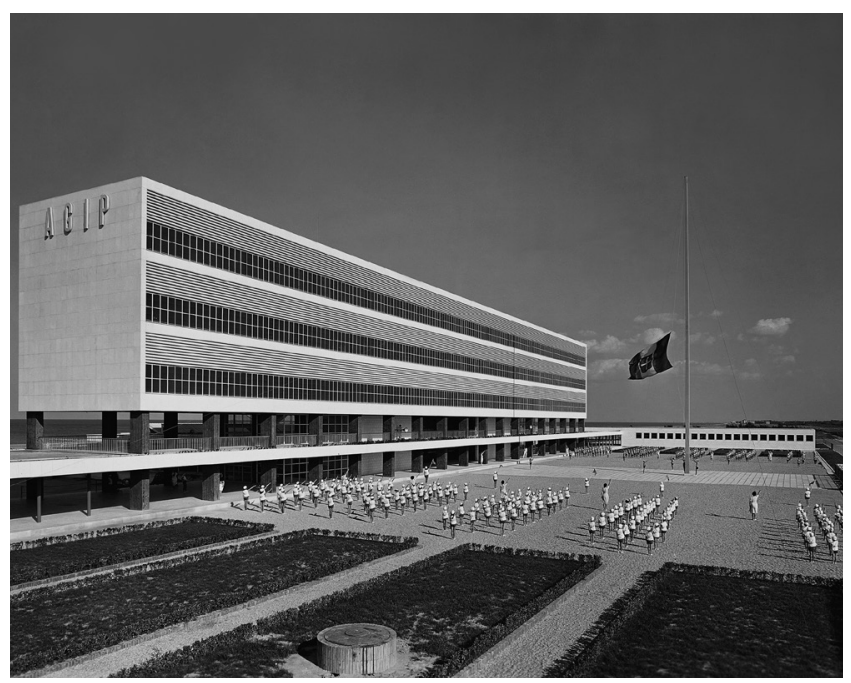

06 Giuseppe Vaccaro, AGIP "Sandro Mussolini" colony, Cesenatico, Forli-Cesena 1937-1938. @ Archivio Giuseppe Vaccaro, Rome.

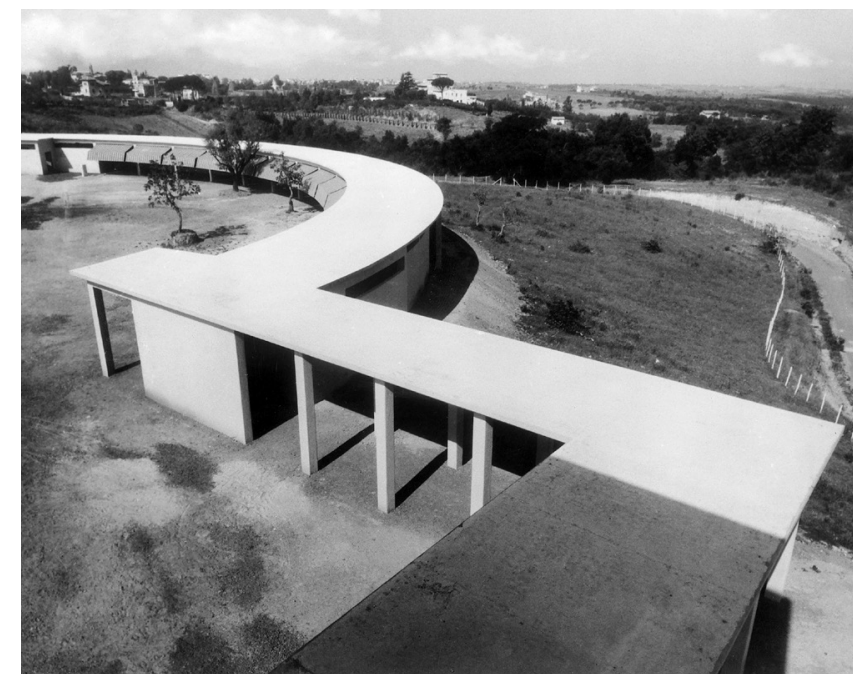

07 Enrico del Debbio, ONB heliotherapy day camp at Monte Mario, Rome 1933- 1934. () Private archive, Venice. 


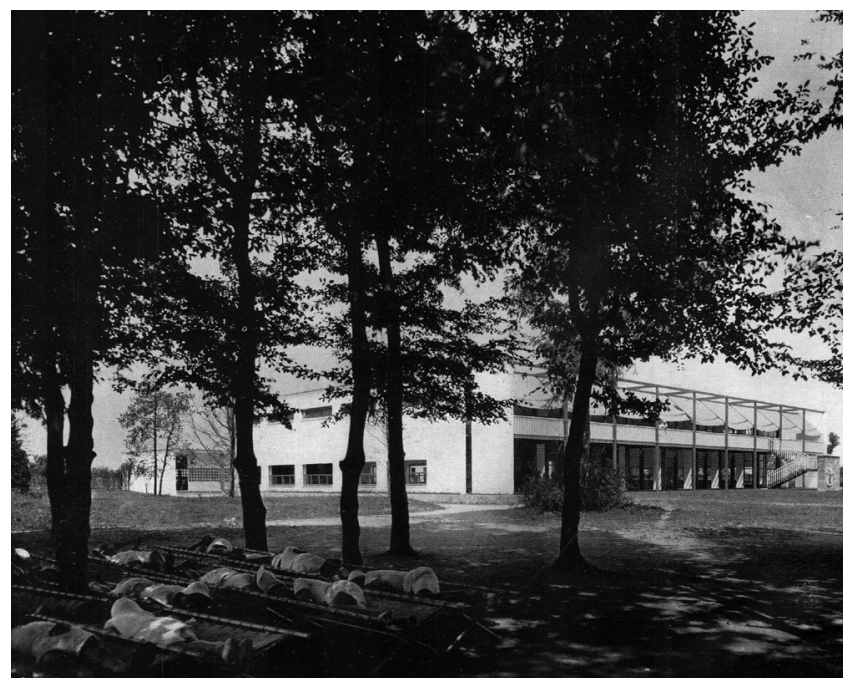

08 BBPR (Gian Luigi Banfi [1910 - 1945], Lodovico Barbiano di Belgiojoso [1909-2004], Enrico Peressutti [1908-1976], Ernesto Nathan Rogers [1909-1969]), heliotherapy day camp, Legnano (Milan), 1938 (C) Costruzioni Casabella, No. 168, December 1941.

community life, from the size and type of window frames to the design of railings, from the plaster to the flooring, colors and materials, contributes - dining ball and cleaning rooms, dormitories and gymnasiums - to create the plastic form, the visual image with which these young people will always identify in memory, the memory of their stay at the colony. It is here that most of them (...) for the first time, in a calm and comfortable life, will be stimulated to allow - albeit passively — the suggestion of a taste to penetrate their being, the first stimuli of appreciation of an architectural form not seen only from the outside, but also experienced by living inside it. And this is the substantial point.

Prior to examining the various projects, Mario Labò supplies orientations on type and form: the colony organized in pavilions, the tower or in any case vertical arrangement (with or without a base), the single linear block (with or without auxiliary pavilions), the open plan, and so on. For each construction he analyzes the composition of the plans, volumes and spaces, evaluating the correctness and efficacy in relation to the context; he sheds light on qualities such as strict compliance with "rationalist" schemes, honest simplicity or compositional finesse, concession to or intelligent interpretations of local themes. He criticizes formalist solutions, contrived attempts at movement of volumes, expedients that cannot compensate for the lack of unified control of the architectural organism. The detailed judgments of the single works of architecture substantially reflect the cultural line of Costruzioni Casabella - which perhaps helps to explain the exclusion of works considered "falsely modern", such as the colonies of Angiolo Mazzoni or Mario Loreti. A "partial” assessment, then, to be observed in the more general context of the debate in which the magazine directed by Giuseppe Pagano was engaged at the time against the "antimodern" and "monumental" leanings of the regime; but also a way of taking stock that conveys the "architectural problem of the colony, an indubitably original feature of today's Italy, [and] formidable in terms of the technical and poetic elements its presence implies", the degree of absolute expression of modernity.

As we know, the constructed heritage produced in Italy in the years of Fascism was not rejected after wwII. The many constructions that survived the war intact met with natural continuity of use, as in the cases of post offices or railway stations; or were involved in more or less problematic reutilizations, paying the price of sizeable transformations, as in the cases of the Case del Fascio and the Balilla centers. Where the colonies were concerned, most of those not damaged during the war (when they were used as magazines, hospitals, military shelters, etc.), pragmatically stripped of the most obvious symbols of the power of the regime, continued to perform their original function for several decades. Furthermore, a sizeable number of new colonies was built until the end of the 1960s, though few of the new ones were comparable in architectural value to the colonies of the 1930s. The decline of these constructions began later, as the result of interwoven causes ranging from the changes in social habits to the more prosaic focus on areas of potential appeal for real estate investment, all within the context of a general lack of interest in "the architecture of the modern era”. Initiated halfway through the 1980s, the activities of documentation and debate on the conservation of the colonies have had to leave many "wrecks" along the way in a process that can certainly not be considered complete. Even today, in the face of a few dozen cases of recovery and reuse still too constrained by the necessity to "valorize" heritage, we can still observe a lack of "exemplary" projects.

\section{Acknowledgments}

Translation by Transiting/ S. Piccolo

\section{Notes}

1 Fascism in Italy corresponds to the National Fascist Party government from 1922 to 1943 with Benito Mussolini as head of government. The Italian Fascists imposed totalitarian rule and suppressed any political and intellectual opposition, while promoting economic modernization, traditional social values from a rapprochement with the Roman Catholic Church.

2 Giuseppe Pagano, "La Mostra delle colonie estive e dell'assistenza all'infanzia”, Casabella, No. 116, Milano, Editoriale Domus, August 1937, 6-15.

3 Planned since 1936, the exhibition had an organizing committee chaired by the secretary of the PNF Achille Starace, with representatives of the many agencies involved in the field of children's aid, demonstrating the importance attributed to the initiative; the overall architectural design was assigned to Adalberto Libera, Mario De Renzi and Giovanni Guerrini. Cf. La città dell'infanzia, Milano, Salocchi, 1937.

4 Legislation of 3 April 1926, No. 2247, Istituzione dell'Opera Nazionale Balilla per l'assistenza e l'educazione fisica e morale della gioventù.

5 Luigi Moretti was the designer of the ONB pavilion at the Circo Massimo and of the exhibition at Foro Mussolini.

6 "Sintesi del regime", speech given by Mussolini in Rome on 14 March 1934. The words of Mussolini formed the epigraph of the catalogue of the summer camp exhibition.

7 The statements are by Renato Ricci; cf. the commemorative volume Il Foro Mussolini, Milano, Bompiani, 1937.

8 Gian Carlo Jocteau (ed.), Ai monti e al mare. Cento anni di colonie per l'infanzia, Milano, Fabbri Editore, 1990.

9 The ONMI was founded with the legislation of 10 December 1925, No. 2277; the regulation was issued with R.D.L. (Royal Decree Law) on 21 October 1926, No. 1904, parallel to the creation of ONB. One of 
the missions of ONMI was the "classification" of the state of health of children, in order to assign them to different types of facilities.

10 The direct involvement of the party in childhood assistance, also through the creation of camps by its local federations, reflected the desire of Fascism to spread its influence over the younger generations, in explicit competition with the existing world of Catholic and secular associations; this is the perspective behind the definitive distinction, in 1928, between permanent healthcare colonies reporting exclusively to the ONMI, and summer climate camps (by the sea, in the mountains and - starting in 1929 - for heliotherapy) for short stays or operating as day camps, controlled by the PNF.

11 Silvia Inaudi, A tutti indistintamente. L'Ente Opere Assistenziali nel periodo fascista, Bologna, CLUEB, 2008, in particular chapter IV, Tra assistenza e formazione: le colonie per linfanzia.

12 Enrico del Debbio, Progetti di costruzioni. Case balilla-palestre-campi sportivi-piscine ecc., Roma, Palazzo Viminale, 1928. Enrico del Debbio himself was responsible for the review of the Balilla center projects submitted by the local offices for approval.

13 Luigi Moretti, "Case del Balilla", Lo Sport fascista, No. 4, Milano, S.A. Poligrafica Degli Operai, April 1936, 20.

14 Rinaldo Capomolla, Marco Mulazzani, Rosalia Vittorini, Case del balilla. Architettura e fascismo, Milano, Electa, 2008. "Exemplary" works by Moretti for ONB in Rome are the Balilla center of Trastevere (19321937) and the "Casa delle armi" at Foro Mussolini (1933-1936). In 1934 two circulars of the ONB definitively established the role of the central presidency in the choice of designers, and emphasized the discretionary authority of the technical division for the purpose of ensuring homogeneity of the criteria in the design of the Case Balilla.

15 Raffaello Ricci, "Lufficio di Assistenza Sociale nel 1931", Capitolium, No. 3, Treves-Treccani-Tumminelli, Roma, March 1932, 111. Raffaello Ricci was the Italian delegate at the Conférence Internationale des Colonie de vacances et oeurres des plein air held in Geneva in August 1931.

16 In the first half of the 1930 s the overall number of colonies, including the day camps, grew from 1,197 (for 242,233 children) in 1931 to 3,821 (for 652,749 children) in 1936; the seaside and mountain colonies (it is not specified if they were all overnight camps) were 498 in 1932 and 900 in 1936; see Silvia Inaudi, A tutti indistintamente. L'Ente Opere Assistenziali nel periodo fascista, Bologna, CLUEB, 2008. Immediately after the war, the survey of buildings already owned by the GIL (Gioventù Italiana del Littorio, which absorbed the ONB in 1937) recorded the existence of 340 constructions for colonies; see "Commissariato Nazionale della “Gioventù Italiana”, Proprietà immobiliari della G.I. distribuite per regioni e provincie, Roma, Tipografia F.lli Lamagna, 1948. In 1953 a survey of the holdings of Gioventù Italiana reduced the number of colonies to 287 .

17 Fulvio Irace, “Lutopie nouvelle: l'architettura delle colonie", Domus, No. 659, Editoriale Domus, Milano, March 1985, 2.

18 Giulio Pediconi, interview in Stefano de Martino, Alex Wall, Cities of Childhood. Italian Colonies of the 1930s, London, The Architectural Association, 1988, 75 .

19 Formed spontaneously in 1919, the "Fasci Italiani all'Estero" were a branch of the PNF outside of Italy. Gathered for a congress in Italy in 1925, they were supplied with a statute by Mussolini in January 1928. As of 1937, 27 colonies had been built for this organization.

20 "Depuis une dizaine d'année, l'Italie fait un très serieux effort en faveur de la santé de la race", Pierre Vago, "Colonie de vacances à Tirrenia", L'Architecture d'Aujourd'bui, No. 10, Paris, Éditions de L'Architecture d'Aujourd'hui, October 1936, 61-63 (Colony by Angiolo Mazzoni at Calambrone). In No. 4, April 1934, the magazine covered the colonies by Clemente Busiri Vici at Cattolica and by Gaspare and Luigi Lenzi at Santa Severa. In No. 7, July 1939, on the theme of "Vacances et loisirs", in the section "Colonies de vacances en Italie" as many as eight colonies were illustrated: Daniele Calabi (1906-1964) at Lido di Venezia, Gino Levi-Montalcini at Bardonecchia, Paniconi \& Pediconi (architectural firm) at Tirrenia, Giulio Minoletti at Formia, Giuseppe Vaccaro at Cesenatico, Fratino \& Griffini (architectural firm) at Cesenatico, BBPR at Legnano, the heliotherapy camp in Turin (created in the unfinished villa of Riccardo Gualino [1879-1964] on a hill in Turin); the issue included a text by Gino Lèvi-Montalcini.

21 Gio Ponti, "Stile di Vaccaro", Stile, No. 27, Garzanti Editore, Milano, March 1943, 7 .

22 For example: Clemente Busiri Vici had ongoing relations with the Federazione dei Fasci Italiani all'Estero, Vittorio Bonadè Bottino was the head of the construction division of FIAT, Angiolo Mazzoni was a functionary of the Ministry of Postal Services and Telecommunications, Giuseppe Vaccaro was commissioned by his uncle Ernesto Puppini, then the president of Agip, Gaspare and Luigi Lenzi were building the new Ospedale Santo Spirito in Rome, both Giovanni Greppi and Enrico Griffini designed industrial and private buildings for Dalmine and for the Redaelli family, Enrico del Debbio and Francesco Mansutti and Gino Miozzo were "staff" architects of ONB and received commissions directly from Renato Ricci, while Mario Loreti did various projects for the municipality and PNF of Varese.

23 The winners of the competition of Riccione, Ettore Sottsass and Alfio Guaitoli, did not see their project built, but in 1937 they received the commission from the Turin federation for the colony at Marina di Massa. Held in 1936, the competition for a Montecatini colony at Marina di Ravenna led to prizes for various interesting projects, though none of them were built.

24 "Esito dei concorsi indetti dal PNF in occasione della Mostra delle Colonie estive e dell'assistenza all'infanzia”, Supplemento Sindacale, No. 6, 15 April 1938, 84 .

25 The legislation R.D.L. 3 June 1937, No. 847, Istituzione in ogni comune del Regno dell'Ente Comunale di Assistenza. R.D.L. 27 October 1937, No. 1839, Istituzione della Gioventù italiana del Littorio. "Foglio d'ordine" of the PNF 29 October 1937, No. 187.

26 Giovanni Battista Allaria, "Incremento delle Colonie diurne in rapporto all'assistenza totalitaria del PNF. Relazione al Congresso nazionale sulla vigilanza e propaganda igienica nelle colonie estive e nell'assistenza all'infanzia", La pediatria del medico pratico, No. 8, 1937.

27 Armando Melis, Caratteri degli edifici. Distribuzione, proporzionamento, organizzazione degli edifici tipici, Torino, Editrice Libraria Italiana, 1939. Gio Ponti, "Problemi italiani dell'abitazione al mare", Domus, No. 152, Milano, Editoriale Domus, August 1940, 19.

28 Mario Labò, Attilio Podestà (ed.), “Colonie marine e montane”, Costruzioni Casabella, No. 167 and No. 168, Milano, Editoriale Domus, November and December 1941. The first volume presented 16 seaside colonies ( 14 built and 2 as projects); in the second, 9 mountain colonies ( 7 built and 2 as projects) and 7 heliotherapy camps ( 6 built and 1 as project). By the same authors, the volume Colonie marine, montane, elioterapiche, Milano, Editoriale Domus, 1942.

\section{References}

BALDUCCI, Valter (ed.), Architetture per le colonie di vacanza. Esperienze europee, Alinea, Firenze 2005.

CAPOMOlla, Rinaldo, MUlaZZANi, Marco, vitToRini, Rosalia, Case del balilla. Architettura e fascismo, Milano, Electa, 2008.

DE MARTino, Stefano, WALl, Alex, Cities of childhood. Italian colonies of the 1930s, London, The Architectural Association, 1988.

Dubowitz, Dan, Fascismo abbandonato. Le colonie d’infanzia nell'Italia di Mussolini, Stockport, Dewi Lewis Publishing, 2010.

FRANCHINI, Francesca, Colonie per linfanzia tra le due guerre. Storia e tecnica, Sant'Arcangelo di Romagna, Maggioli Editore, 2009.

INAUDI, Silvia, A tutti indistintamente. L'Ente Opere Assistenziali nel periodo fascista, Bologna, CLUEB, 2008.

IRACE, Fulvio, "Lutopie nouvelle: l'architettura delle colonie", Domus, No. 659, Editoriale Domus, Milano, March 1985, 2-29.

ISTITUTO PER I BENI CULTURALI DELLA REGIONE EMILIA-ROMAGNA (ed.), Colonie a mare. Il patrimonio delle colonie sulla costa romagnola quale risorsa urbana e ambientale, Bologna, IBC Regione Emilia-Romagna, Graphis, 1986.

Jocteau, Gian Carlo (ed.), Ai monti e al mare. Cento anni di colonie per linfanzia, Milano, Fabbri Editore, 1990.

LABÒ, Mario, PODESTÀ, Attilio (ed.), "Colonie marine e montane", Costruzioni Casabella, No. 167 and No. 168, Milano, Editoriale Domus, November and December 1941.

\section{Marco Mulazzan}

Associate professor of History of architecture at the Ferrara University. He is member of the editorial board of the magazine Casabella. His studies focus on $20^{\text {th }}$ century Italian architecture, deepening with essays and volumes the work of architects such as Luigi Moretti, Giuseppe Vaccaro and others. 